O. Yu. Mohylevska1, Cand. Sc. (Econ.), Assoc. Prof., orcid.org/0000-0001-8482-7950,

L. V. Romanova ${ }^{2}$, Dr. Sc. (Econ.), Prof., orcid.org/0000-0003-2292-6616,

V.P.Zalizniuk ${ }^{2}$, Cand. Sc. (Econ.), orcid.org/0000-0002-7014-0207, N. V. Kovalenko ${ }^{3}$, Cand. Sc. (Econ.), Assoc. Prof., orcid.org/0000-0001-8011-1373,

S. M. Demydiuk ${ }^{4}$, Cand. Sc. (Econ.), orcid.org/0000-0001-7911-7460
1 - Kyiv International University, Kyiv, Ukraine, e-mail: olgaym1993@gmail.com

2 - Interregional Academy of Personnel Management, Kyiv, Ukraine, e-mail: romanovalida@ukr.net; v.zalizniuk@gmail.com 3 - National Aviation University, Kyiv, Ukraine, e-mail: kovalenko-nv@ukr.net

4 - Academician Stepan Demianchuk International University of Economics and Humanities, Rivne, Ukraine, e-mail: sergej080@ukr.net

\title{
MARKETING MECHANISMS FOR IMPROVING THE EFFICIENCY OF INDUSTRIAL ENTERPRISES
}

Purpose. The paper deals with the problems of formation and application of marketing mechanisms to increase the efficiency of industrial enterprises. Under the current economic conditions of the development and course of globalization processes, ensuring the effective activity of leading industries and their subordinate enterprises is a matter of extreme topicality and urgency. Timely and purposeful use of marketing mechanisms in the business activity of an enterprise is the key to its progressive development.

Methodology. In the course of the works, the methods of theoretical generalization, comparison, synthesis, analysis were used to reveal the general principles and to determine the basic categories of the study.

Findings. The application by industrial enterprises of an integrated approach based on the close interaction of market mechanisms and the production process with mandatory relying on modern marketing mechanisms is necessary to increase their efficiency. Increased competition caused by globalization processes is forcing industrial enterprises to improve their performance and manage their monitoring in order to influence the competitiveness of their products. Under the current conditions of development, there is a need to intensify marketing mechanisms in the activities of industrial enterprises, which will lead to the acquisition of leadership positions in the market and provide competitive advantages in it. The analysis of scientific publications made it possible to systematize approaches to gaining competitive advantages. It is established that in order for marketing mechanisms for improving the efficiency of industrial enterprise operation to give maximum effect, it is advisable to apply innovation. It was analyzed how marketing and organizational innovations were implemented at industrial enterprises. It is established that flexible production systems with the use of marketing approaches should play a key role in ensuring the economic process and organization of production at an industrial enterprise.

Originality. The scientific research conducted reveals the need to find and propose marketing mechanisms to improve the efficiency of industrial enterprises, which is especially relevant in the context of economic and political instability and the uncertainty of environmental factors. The results of the research made it possible to determine the stages of application of the innovation profile in these marketing mechanisms. Based on the analysis of innovation activity of industrial enterprises, it is determined that the problems of inhibiting innovative progress relate not only to technical or technological processes, but also to marketing approaches and mechanisms for organization of production and sales of products. The information obtained serves as a catalyst for defining a comprehensive approach based on the close interaction between market mechanisms and the production process, with mandatory relying on modern marketing mechanisms.

Practical value. The results of the study can be used by practitioners, scientists, government officials to apply marketing mechanisms and a systematic approach in managing and organizing production at industrial enterprises, which will influence the improvement of the competitiveness of the Ukrainian industry as a whole.

Keywords: marketing, management, marketing mechanisms, evaluation, efficiency, industry

Introduction. The development of globalization processes and the intensification of competition between manufacturers are the conditions in which domestic industrial enterprises have now to conduct their economic, production and management activities. It is appropriate that, according to these challenges, industrial enterprises are being increasingly required to increase the efficiency of their operation and the competitiveness of their products. In this case, the efficiency of an industrial enterprise depends on its ability to respond in a timely and correct manner to changes occurring both in the external and the internal environment [1]. The purpose - improving the efficiency of operation - is reflected in the strategy of development, in the economic policy of an industrial enterprise in the form of making appropriate management decisions. Accordingly, there is a need for the development and implementation of marketing mechanisms that allow predicting with the utmost accuracy the needs of consumers and ensuring the efficiency of the industrial enterprise.

(C) Mohylevska O. Yu., Romanova L. V., ZalizniukV. P., Kovalenko N. V., Demydiuk S. M., 2020
Increased competition caused by globalization processes is forcing industrial enterprises to improve their performance and manage their monitoring in order to influence the competitiveness of products. Under the current conditions of development, there is a need to intensify marketing mechanisms in the activities of industrial enterprises, which will lead to the acquisition of leadership positions in the market and provide competitive advantages in it. The role of marketing mechanisms as one of the main systems of any enterprise is growing significantly, which ensures the connection of the industrial enterprise with the external environment and its production system.

Literature review. Theoretical, methodological and practical problems of the theory and practice of general marketing are revealed in scientific works by such world-renowned economists as: B.Andersen, P.Cherrington, R. Breyer, R. Cox, A. Shrow, R. Alderson, P. Blissy, T. Levitt, J. Evans, F. Kotler, D. Levy, R. Butler, D. Dell, P. Drucker, J. Bowen, J. Makens, R. Krendel, J. Lambin, S. Majaro, A. Hiam, B. Berman, I. Ansoff, B. Karleff, and T. Ambler.

Domestic scientists such as: M. Yermoshenko, N. Chumachenko, O.Amosha, A.Akmayev, M.Korzh, N. Meshko, 

issues.

Unsolved aspects of the problem. There is little research on the marketing mechanisms for improving the efficiency of industrial enterprises. This is due to a wide range of problems that are related to marketing mechanisms and concern all areas and processes at an industrial enterprise - in particular, lack of a general mechanism for marketing management at an industrial enterprise taking into account the specifics of activity, lack of evaluation of the efficiency of marketing mechanisms at industrial enterprises, and lack of approaches to forecasting the results of improving marketing measures and mechanisms applied, and others.

In this regard, there is a need to find and propose marketing mechanisms to improve the efficiency of industrial enterprises, which is especially relevant in the context of economic and political instability and the uncertainty of environmental factors.

The purpose of the article is to research the marketing mechanisms for improving the efficiency of industrial enterprises.

Methods. In the process of writing the article, the methods of theoretical generalization, comparison, synthesis, analysis were used to describe the general principles and determine the basic categories of the study.

Results. Conducting a comprehensive study on the activity of an industrial enterprise, its evaluation and analysis are the basis for successful modeling its production system. However, as practice shows, this is not enough. Indeed, under the current economic conditions of the development and course of globalization processes, ensuring the effective activity of leading industries and their subordinate enterprises is a matter of extreme topicality and urgency. Timely and purposeful use of marketing mechanisms in the economic activity of an enterprise is the key to its progressive development [2]. In the context of market relations, the activities of an enterprise, including an industrial one, is characterized by the expansion of the independence of management, the development of various forms of ownership, the aggressiveness of competitive battle and the increased instability of the external environment. These changes have led to an increase in requirements for the system of managing the activity of an industrial enterprise [3]. The priority now is to ensure their survival, which is impossible without marketing, the rapid use of its marketing mechanisms.

Scientific studies conducted by domestic scientists have shown that a prerequisite for improving the functioning of an industrial enterprise is the introduction of preventive measures:

- into the system and structure of industrial enterprise management;

- the introduction of market approaches into the commodity, price, marketing and communication policy of an industrial enterprise;

- the initiation of innovative activity;

- the activation of innovation and investment activity [4-6].

The defined list of preventive measures is justified, because, in a competitive environment, industrial enterprises should not only concentrate on the internal state of affairs, but also focus on changes in the external environment. To this end, it is necessary to develop a long-term survival strategy that is adjusted to changes in external and internal conditions as well as ensures the adaptation of the industrial enterprise. Marketing plays an important role in this process, because it is a factor that ensures interconnections between industrial enterprises, industries, and countries.

To improve the efficiency of an industrial enterprise, scientists propose to use such marketing mechanisms that can be adapted to market requirements if necessary (Table 1).

Marketing mechanisms improving the efficiency of an industrial enterprise

\begin{tabular}{|l|l|l|l|}
\hline Market type & \multicolumn{1}{|c|}{ Product } & Production type & Marketing type \\
\hline $\begin{array}{l}\text { Innovative } \\
\text { market }\end{array}$ & $\begin{array}{l}\text { New } \\
\text { product }\end{array}$ & $\begin{array}{l}\text { Individual } \\
\text { production }\end{array}$ & $\begin{array}{l}\text { Innovative } \\
\text { marketing }\end{array}$ \\
\hline $\begin{array}{l}\text { Monoge- } \\
\text { neous market }\end{array}$ & $\begin{array}{l}\text { Standard } \\
\text { product }\end{array}$ & Mass production & $\begin{array}{l}\text { Optimization } \\
\text { marketing }\end{array}$ \\
\hline $\begin{array}{l}\text { Homoge- } \\
\text { neous market }\end{array}$ & $\begin{array}{l}\text { Popular } \\
\text { product }\end{array}$ & $\begin{array}{l}\text { Customized } \\
\text { production }\end{array}$ & Brand marketing \\
\hline
\end{tabular}

Therefore, Table 1 shows that the appropriate use of a certain type of marketing, depending on the type of market, product and the type of production, is able to ensure to the industrial enterprise success in the market. It should be noted that the efficiency of the production process at an industrial enterprise is achieved through the stability and controllability of all processes. Marketing is also a link between the market and the manufacturer, while addressing two major challenges:

1) it determines the vectors of necessary changes and the opportunities for economic development of the industrial enterprise while developing the available and potential opportunities;

2) it contributes to the improvement of socio-economic indicators and helps the perception of changes in society [7].

Those enterprises that combine production and marketing mechanisms are cost effective; this combination has a synergistic effect and must be reflected in the strategy of the enterprise. Accordingly, one of the primary tasks of an industrial enterprise is the development of a marketing strategy, which a priori envisages improving the efficiency of the industrial enterprise. It is also based on a competitive strategy that is aimed at generating competitive advantages in the relevant sectoral market [8].

Porter M. worked on the formation and implementation of a competitive strategy back in the 1980s. In his opinion, the essence and content of a competitive strategy is to "find a clear formulation of how the enterprise will compete, what its goals should be and what funds and actions will be needed to achieve those goals" [7]. In this context, it is advisable to present the relationship between marketing and production in the form of Fig. 1.

Analyzing Fig. 1, we can conclude that each company chooses the approaches to gaining competitive advantages based on:

- competitors, in this case, the focus is on reducing costs, which leads to the formation of price advantage;

- consumers who prefer more competitive goods [10]. At the same time, it is necessary to ensure the necessary utility of goods, which is achieved through the interaction of the production and marketing subsystems of an industrial enterprise.

In order for the marketing mechanisms for improving the efficiency of an industrial enterprise's operation to give the maximum effect, it is advisable to apply innovations, which, in Fig. 1, are listed as the "innovation profile"; they have their stages of application (Fig. 2).

To continue the study, we will analyze what innovations were introduced by industrial enterprises (Table 2).

The data in the table show that problems of the slowdown of innovative progress relate not only to engineering or technological processes, but also to marketing approaches and mechanisms for organization of production and sales of products. Most businesses did not introduce any marketing approaches (including innovative ones) into their own manufacturing or organizational activities. In particular, enterprises engaged in the manufacture of machinery and equipment in 2017 introduced only $25 \%$ of organizational and marketing innovations 


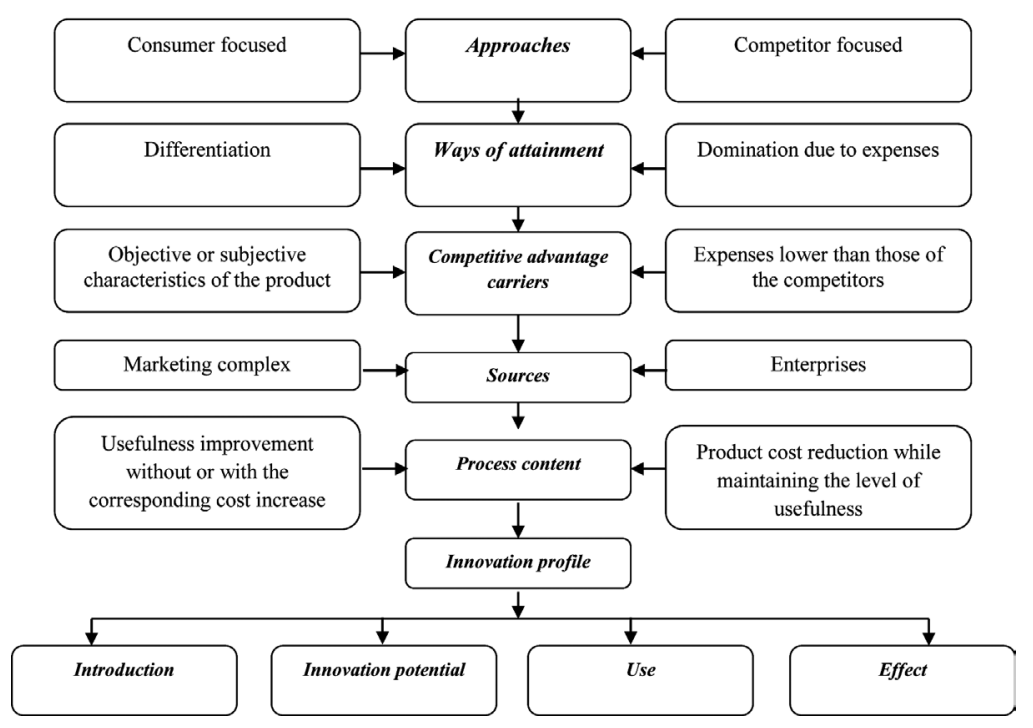

Fig. 1. Approaches to gaining competitive advantages [9]

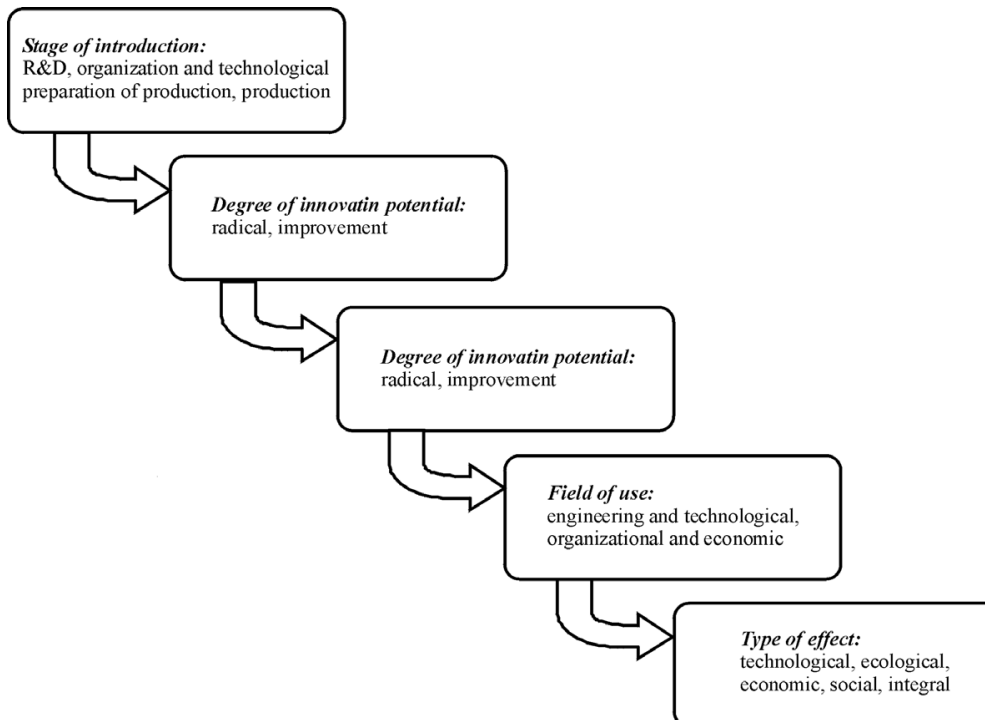

Fig. 2. Stages of application of the profile of innovations in marketing mechanisms for increasing the efficiency of an industrial enterprise $[9,3,6]$

compared with the level of 2011; the situation changed only slightly in 2018 compared to the base year 2011.

Thus, it can be concluded that enterprises are not interested in introducing new marketing mechanisms into their production activities, activities related to the introduction of new sales methods, activities related to changes in products, methods and conditions of their storage, activities to promote products in the market or price policies, activities to open up new markets for sale or to conquer market sectors [12].

Let us analyze how marketing and organizational innovations were implemented at industrial enterprises; we will present the data obtained in Table 3.

Given the unsatisfactory state of the innovative approach to management and marketing, we believe that the problem that needs to be solved is lack of experience in using marketing by industrial enterprises. The basic marketing mechanisms should underlie all economic activities of industrial enterprises and their innovation policy. Without marketing orientation and the interaction of economic, organizational, production and marketing subsystems, industrial enterprises will not be able to increase the efficiency of operation and to meet the needs of the market.
Conclusions. Industrial enterprises need to reorient the production in line with the requirements of today's market and consumers. They should apply the "reach" strategy which allows achieving high efficiency, offering at the same time customized products. Paradoxically, both mass production and customized production are capable of working successfully within a single enterprise. Both mass nature of production and adaptation to the requirements and needs of the consumer (customization), provided they are based on marketing principles, will enable mass production of products from standard components and production with individualization of the final product [3].

Also, in order to increase the efficiency of industrial enterprises, it is advisable to constantly monitor the latest marketing trends and to consider the possibility of their implementation in economic activity. Among the modern marketing trends in 2019, the following ones are singled out:

1. Chatbots. Approximately 1.4 billion people communicate with chatbots each year. This number of potential consumers allows identifying their needs and desires and, thus, adjusting the activities of the industrial enterprise. It is advisable to use chatbot technologies to identify not only the needs of the consumer, but also to build an effective economic, pro- 
Innovative activity of industrial enterprises in 2011-2018 [11-13]

\begin{tabular}{|l|c|c|c|c|c|c|c|c|c|}
\hline \multicolumn{1}{|c|}{ Indicator } & 2011 & 2012 & 2013 & 2014 & 2015 & 2016 & 2017 & 2018 \\
\hline \multicolumn{2}{|c|}{ The number of enterprises engaged in innovative activities } \\
\hline Production of machines and quipment & 978 & 986 & 955 & 927 & 865 & 796 & 799 & 803 \\
\hline Production of electrical, electronic and optical equipment & 616 & 639 & 644 & 610 & 577 & 477 & 485 & 489 \\
\hline Production of transport equipment & 294 & 300 & 282 & 274 & 286 & 247 & 233 & 241 \\
\hline \multicolumn{7}{|c|}{ The number of industrial enterprises introducing innovations } \\
\hline Production of machines and equipment & 156 & 160 & 163 & 181 & 163 & 113 & 110 & 108 \\
\hline Production of electrical, electronic and optical equipment & 137 & 136 & 138 & 135 & 126 & 121 & 119 & 115 \\
\hline Production of transport equipment & 61 & 62 & 72 & 73 & 77 & 82 & 61 & 64 \\
\hline
\end{tabular}

Table 3

Dynamics of the introduction of marketing and organizational innovations by industrial enterprises in 2011-2018 [11-13]

\begin{tabular}{|c|c|c|c|c|c|c|c|c|}
\hline Indicator & 2011 & 2012 & 2013 & 2014 & 2015 & 2016 & 2017 & 2018 \\
\hline \multicolumn{9}{|c|}{ Organizational innovations } \\
\hline Production of machines and equipment & 44 & 50 & 40 & 35 & 29 & 9 & 12 & 15 \\
\hline Production of electrical, electronic and optical equipment & 31 & 24 & 18 & 22 & 14 & 13 & 8 & 9 \\
\hline Production of transport equipment & 20 & 20 & 12 & 12 & 15 & 11 & 11 & 13 \\
\hline \multicolumn{9}{|c|}{ Marketing innovations } \\
\hline Production of machines and equipment & 44 & 43 & 33 & 30 & 25 & 12 & 11 & 13 \\
\hline Production of electrical, electronic and optical equipment & 24 & 25 & 18 & 20 & 10 & 14 & 12 & 14 \\
\hline Production of transport equipment & 19 & 17 & 13 & 14 & 12 & 7 & 12 & 15 \\
\hline
\end{tabular}

duction, marketing and management mechanism for the operation of the industrial enterprise.

2. Interactive video content. The implementation of the possibility of interactive production process monitoring at industrial enterprises enables potential consumers to become customers of the industrial enterprise. Thanks to the ability to observe the product life cycle, the awareness of both an individual brand and the company as a whole is increased several-fold.

3. Customers' personalization with artificial intelligence. This marketing approach consists in giving the customer the service he/she wants as accurately and personally as possible; it relates to personalized offers and discounts, the availability of online platforms with the possibility for the client of logging in through his/her personal office, where he/she will be offered up-to-date offers concerning product, prices, delivery terms, and others.

4. Predictive analytics. This tool works for the manufacturer rather than for the customer, although it takes into account his/her wishes. Indeed, using modern capabilities of personal computers and their software, one can create an information field that will allow determining which advertising is of interest to the consumer, what will be the traffic of supply of material, and so on [13].

Flexible manufacturing systems using marketing approaches should play a key role in ensuring the business process and organization of production at an industrial enterprise. This will make it possible to produce and market products with different modifications, which will significantly expand the existing range of goods. This will directly affect the speed of response when demand changes. In the process of production management and adherence to production technology of an industrial enterprise, it is necessary to introduce computerization of the process, and, at other stages, to use marketing information. It will allow organizing an effective system of receipt, processing and execution of orders for customized products. Due to the use of marketing mechanisms, it will be possible to predict the characteristics of products to meet the re- quirements of the consumer and the capabilities of the manufacturer (an industrial enterprise) [14, 15]. This integrated approach in organization of production, management and technology at an industrial enterprise with use of marketing approaches will provide both the "scale effect" and the "reach effect" in the market, which will ultimately lead to an improved efficiency of the industrial enterprise.

Therefore, the use by industrial enterprises of an integrated approach based on the close interaction of market mechanisms, the latest marketing trends and the production process, with mandatory relying on modern marketing mechanisms, is necessary to increase their efficiency. The fastest implementation of marketing mechanisms to improve the efficiency of industrial enterprises will be facilitated by:

1) the exchange of practical experience between industrial enterprises;

2) the coexistence of different approaches and marketing mechanisms at an industrial enterprise;

3) the introduction of advanced technologies, organizational and managerial innovations at industrial enterprises.

Therefore, the more industrial enterprises will use the existing marketing mechanisms and a systematic approach to production management and organization, the better it will affect the efficiency of their operation and, ultimately, the improvement of the competitiveness of the Ukrainian industry as a whole.

\section{References.}

1. Shtuler, I. (2015). Innovative approach to determining integrated marketing communications to ensure development of national forest complex. A new role of marketing and communication technologies in business and society: local and global aspects: collective monograph. Publishing House Science and Innovation Center, Ltd.

2. Hakyeon, L., Sang Gook, K., Hyun-woo, P., \& Pilsung, K. (2013). Pre-launch new product demand forecasting using the Bass model: A statistical and machine learning-based ap- 
proach. Technological Forecasting and Social Change, 86, 4964.

3. Korzh, M., \& Zhukov, S. (2013). Psychological aspects of change management in the industrial marketing. Journal of Law and Psychology, 4(1), 28-37.

4. Internet-trends of 2019. Statistics and facts in the USA and in the whole world. Retrieved from https://uk.vpnmentor.com/ blog.

5. Solokha, D. (2013). Marketing principles of positioning of innovative-active enterprises in the international economic space. In Marketing of innovations and innovation in marketing: collection of theses of lectures of VII International scientific-practical conference, (pp. 261-262). Sumy. Retrieved from https:// essuir.sumdu.edu.ua /bitstream/123456789/37525/1/Solokha international\%20economics.pdf.

6. Shtuler, I. (2014). Organizationally-economic pre-conditions of construction of the program of enterprise innovative development. Systems of making decision in an economy, technique and organizational spheres: from a theory to practice: collective monograph. ART Sintes-T.

7. Oklander, M., \& Pedko, I. (2016). Prognostication distribution of innovative or import replaceable production by the enterprises-producers of concrete. Economic Bulletin of the National Technical University of Ukraine "Kyiv Polytechnic Institute", (13), 385-390.

8. Zhukov, S. (2017). Management by the industrial marketing on enterprises: monograph. NAU.

9. Zuhaimy, I., \& Noratikah, A. (2013). New product Demand Forecast based on Bass Diffusion Model. Journal of Mathematics and Statistics, 9(2), 84-90.

10. Zhuk, I. M. (Ed.) (2017). Statistical annual of Ukraine for 2017. Retrieved from http://www.ukrstat.gov.ua.

11. Karmazin, O. O. (Ed.) (2018) Scientific and innovative activity in Ukraine in 2017. Retrieved from http://www.ukrstat.gov.ua.

12. Kuznetsov, M. S. (Ed.) (2019). Scientific and innovative activity in Ukraine in 2018. Retrieved from http://www.ukrstat.gov.ua. 13. Gantsura, A., \& Kovalenko, N. (2017). Features of the marketing dropshopping in the system of electronic commerce. Naukovyi Visnyk Uzhhorodskoho Natsionalnoho Universytetu. Seriia: Mizhnarodni ekonomichni vidnosyny ta svitove hospodarstvo, 15(1), 72-75.

14. Paryzkyi, I. (2017). Competitiveness of national economy as prominent criterion of innovative-technological development of Ukraine economy. Economy and State, 3, 47-50.

15. Romanenko, Y. O., \& Chaplay, I. V. (2016). Marketing communication system within public administration mechanisms. Actual Problems of Economics, 178(4), 69-78.

\section{Маркетингові механізми підвищення ефективності функціонування промислових підприємств}

О. Ю. Могилевська ${ }^{1}$, Л. В. Романова ${ }^{2}$, В. П. Залізнюк ${ }^{2}$, Н. В. Коваленко ${ }^{3}$, С. М. Демидюк

1 - Київський міжнародний університет, м. Київ, Україна, e-mail: olgaym1993@gmail.com

2 - Міжрегіональна академія управління персоналом, м. Київ, Україна, e-mail: romanovalida@ukr.net;v.zalizniuk@ gmail.com

3 - Національний авіаційний університет, м. Київ, Україна, e-mail: kovalenko-nv@ukr.net

4 - Міжнародний економіко-гуманітарний університет імені академіка Степана Дем’янчука, м. Рівне, Україна, e-mail: sergej080@ukr.net

Мета. У роботі порушуються проблеми формування й застосування маркетингових механізмів підвищення ефективності функціонування промислових підприємств. У сучасних економічних умовах розвитку й пере- бігу глобалізаційних процесів забезпечення ефективної діяльності провідних галузей і підпорядкованих їм підприємств - $є$ питанням надзвичайної актуальності та нагальності. Своєчасне й цілеспрямоване використання маркетингових механізмів у господарській діяльності підприємства є запорукою його прогресивного розвитку.

Методика. У процесі роботи застосовувалися методи теоретичного узагальнення, порівняння, синтезу, аналізу - для розкриття загальних положень і визначення базових категорій дослідження.

Результати. Застосування промисловими підприємствами комплексного підходу, що базується на тісній взаємодії ринкових механізмів і виробничого процесу, 3 обов'язковою опорою на сучасні маркетингові механізми $\epsilon$ необхідним для підвищення ефективності їх функціонування. Зростання конкуренції, що спричинене глобалізаційними процесами, спонукає промислові підприємства до підвищення ефективності їх функціонування та управління моніторингом 3 метою впливу на конкурентоспроможність продукції. За сучасних умов розвитку існує необхідність в активізації маркетингових механізмів у діяльності промислових підприємств, що призведе до завоювання лідерських позицій на ринку й забезпечить конкурентні переваги на ньому. Аналіз наукових публікацій дав змогу систематизувати підходи до завоювання конкурентних переваг. Встановлено, що для того, щоб маркетингові механізми підвищення ефективності функціонування промислового підприємства дали максимальний ефект, доцільно застосовувати інновації. Проаналізовано, як упроваджувалися маркетингові та організаційні інновації на промислових підприємствах. Встановлено, що в забезпеченні господарського процесу та організації виробництва на промисловому підприємстві ключову роль повинні відігравати гнучкі виробничі системи з використанням маркетингових підходів.

Наукова новизна. Проведене наукове дослідження розкриває необхідність пошуку та пропонування маркетингових механізмів підвищення ефективності функціонування промислових підприємств, що має особливу актуальність в умовах економічної й політичної нестабільності та невизначеності факторів зовнішнього середовища. Результати дослідження дали можливість визначити стадії застосування профілю інновацій у цих маркетингових механізмах. На основі аналізу інноваційної активності підприємств промисловості визначено, що проблеми гальмування інноваційного прогресу стосуються не лише технічних чи технологічних процесів, але й маркетингових підходів і механізмів до організації виробництва й реалізації продукції. Отримана інформація слугує каталізатором для визначення комплексного підходу, шо базується на тісній взаємодії ринкових механізмів і виробничого процесу, з обов'язковою опорою на сучасні маркетингові механізми.

Практична значимість. Результати дослідження можуть бути використані практиками, науковцями, представниками влади для застосування маркетингових механізмів і системного підходу в управлінні та організації виробництва на промислових підприємствах, що вплине на підвищення конкурентоспроможності промисловості України в цілому.

Ключові слова: маркетинг, управління, маркетингові механізми, оцінювання, ефективність, промисловість

\section{Маркетинговые механизмы повышения эффективности функционирования промышленных предприятий}

\author{
О. Ю. Могилевская ${ }^{1}$, Л. В. Романова ${ }^{2}$, В. П. Зализнюк ${ }^{2}$,
} Н. В. Коваленко ${ }^{3}$, С. М. Демидюк 
1 - Киевский международный университет, г. Киев, Украина, e-mail: olgaym1993@gmail.com

2 - Межрегиональная академия управления персоналом, г. Киев, Украина, e-mail: romanovalida@ukr.net; v.zalizniuk@ gmail.com

3 - Национальный авиационный университет, г. Киев, Украина, e-mail: kovalenko-nv@ukr.net

4 - Международный экономико-гуманитарный университет имени академика Степана Демьянчука, г. Ровно, Украина, e-mail: sergej080@ukr.net

Цель. В работе поднимаются проблемы формирования и применения маркетинговых механизмов повышения эффективности функционирования промышленных предприятий. В современных экономических условиях развития и глобализационных процессов обеспечение эффективной деятельности ведущих отраслей и подчиненных им предприятий - вопрос чрезвычайной актуальности и неотложности. Своевременное и целенаправленное использование маркетинговых механизмов в хозяйственной деятельности предприятия является залогом его прогрессивного развития.

Методика. В процессе работы применялись методы теоретического обобщения, сравнения, синтеза, анализа - для раскрытия общих положений и определения базовых категорий исследования.

Результаты. Применение промышленными предприятиями комплексного подхода, который базируется на тесном взаимодействии рыночных механизмов и производственного процесса, с обязательной опорой на современные маркетинговые механизмы, является необходимым для повышения эффективности их функционирования. Увеличение конкуренции, вызванное глобализационными процессами, побуждает промышленные предприятия к повышению эффективности их функционирования и управления мониторингом с целью влияния на конкурентоспособность продукции. В современных условиях развития существует необходимость в активизации маркетинговых механизмов в деятельности промышленных предприятий, что приведет к завоеванию лидерских позиций на рынке и обеспечит конкурентные преимущества на нем. Анализ научных публикаций позволил систематизировать подходы к завоева- нию конкурентных преимушеств. Установлено, что для того, чтобы маркетинговые механизмы повышения эффективности функционирования промышленного предприятия дали максимальный эффект, целесообразно применять инновации. Проанализировано, как внедрялись маркетинговые и организационные инновации на промышленных предприятиях. Установлено, что в обеспечении хозяйственного процесса и организации производства на промышленном предприятии ключевую роль должны играть гибкие производственные системы с использованием маркетинговых подходов.

Научная новизна. Проведенное научное исследование раскрывает необходимость поиска и предложения маркетинговых механизмов повышения эффективности функционирования промышленных предприятий, имеет особую актуальность в условиях экономической и политической нестабильности, и неопределенности факторов внешней среды. Результаты исследования дали возможность определить стадии применения профиля инноваций в этих маркетинговых механизмах. На основе анализа инновационной активности предприятий промышленности определено, что проблемы торможения инновационного прогресса касаются не только технических или технологических процессов, но и маркетинговых подходов и механизмов в организации производства и реализации продукции. Полученная информация служит катализатором для определения комплексного подхода, который базируется на тесном взаимодействии рыночных механизмов и производственного процесса, с обязательной опорой на современные маркетинговые механизмы.

Практическая значимость. Результаты исследования могут быть использованы практиками, учеными, представителями власти для применения маркетинговых механизмов и системного подхода в управлении и организации производства на промышленных предприятиях, что повлияет на повышение конкурентоспособности промышленности Украины в целом.

Ключевые слова: маркетинг, управление, маркетинговые механизмы, оценка, эффективность, промышленность

Recommended for publication by O.M. Momot, Doctor of Economic Sciences. The manuscript was submitted 14.04.19. 